\author{
V.Yu. Kucheruk ${ }^{1}$, I.P. Kurytnik ${ }^{2}$, Ye.Z. Oshanov ${ }^{3}$, P.I. Kulakov', \\ A.A. Semenov ${ }^{1}$, D.Zh. Karabekova ${ }^{3}$, A.K. Khassenov ${ }^{3}$ \\ ${ }^{1}$ Vinnytsia National Technical University, Ukraine; \\ ${ }^{2}$ The W. Pilecki State Higher School, Oswiecim, Poland; \\ ${ }^{3}$ Ye.A. Buketov Karaganda State University, Kazakhstan \\ (E-mail: karabekova71@mail.ru)
}

\title{
Computer-measuring system of the induction motor's dynamical torque-speed characteristics
}

\begin{abstract}
In the article an efficient method of determining the dynamic torque-speed characteristic of induction motors and the computer-measuring system for its realization is considered. In this method, the additional flywheel is used, the dynamic measurements of the angular speed as a function of time are taken at the start, after the end of the transition process, and at during the self-braking mode of the induction motor. For approximating the data that are obtained as a result of the measurements, the moving average algorithm is used. Also, with the help of this system, the inertia moment, angular speed dependence on time, electromagnetic dynamic moment dependence on time, electromagnetic dynamic power dependence on time, mechanical dynamic power dependence on time, and dynamic loss in rotor winds dependence on time are measured. In the article, the results of experimental measurements of the induction motor characteristics using a proposed computermeasuring system are given. The proposed system is experimental; in the future, it can be used to test induction motors during their production processes.
\end{abstract}

Keywords: computer-measuring system, dynamic torque-speed characteristic, induction motor, moving average algorithm.

The measurement of the dynamical torque-speed characteristic is important in the electrical machine check for all kinds of electrical machines. The three-phase alternating current motors with short-circuit rotors (induction motors) are widely used in a variety of industrial applications due to their rather simple design. Determining the parameters of induction motors by their torque-speed characteristic is important for the proper use of the motors since the torque moment and the mechanical losses must be agree [1]. It is common practice to determine the dependence of the torque moment from the angular speed for the study of a motor characteristics in the static and dynamic modes of its operation.

The authors in [2] consider an efficient method of determining the maximum performance torque-speed characteristic for an induction motor drive. This method is based on a mathematical model that provides a method of calculation for the output power, the apparent power, the power factor, and the efficiency vs the speed. The proposed method is applicable to the analysis of induction motors based on the results of measuring their output characteristics. The authors in [3-6] deal with the practical application of the acceleration method for evaluating induction machine torque-speed and current-speed characteristics. Also, this paper considers the influence of the time measurement on the shape of torque-speed characteristics. However, this method does not take into account the accurate value of the moment of inertia of the electric motor rotor. The authors of [7] describe the measuring method for determining the torque-speed characteristic of an induction machine, which is determined by recording and differentiating the speed signal during the starting of the machine. In the proposed system, the data is gathered using a measuring system based on a digital acquisition card and processed in custom software, built using LabVIEW, on a personal computer. This system does not take into account the mechanical losses on the electric machine shaft and the accurate value of the rotor's moment of inertia. The authors in [7-9] present a measurement method for the determination of the torquespeed characteristics of induction motors, which is in compliance with the IEEE standard test procedure for polyphase induction motors and generators [1]. To implement this method, dynamic measurements of the angular speed as a function of time are carried out. Afterward, digital filtering of the obtained data is carried out, then the dependence of the angular acceleration as a function of time is calculated using digital differentiation. On the basis of this dependence, the torque-speed characteristics are calculated. In this method, the measurements are taken with no load on the motor shaft. The dynamic measurements of the angular speed as a function of time are taken during the start and after the end of the transition process, and the measurements in the process of the self-braking mode are not carried out. The authors in $[10,11]$ describe the use of a 
curve-fitting technique to deduce the nominal torque-speed characteristic of a three-phase induction motor from the speed data obtained in a no-load acceleration test. In paper [12] the authors propose the measuring method of the rotor moment of inertia at the use of various numbers of additional flywheels. In this method, $\mathrm{B}$-splines are used for the processing of measured data obtained during the start. In this case, a determination of the torque-speed characteristics during the self-braking mode is not carried out.

There is a group of methods based on the computation of the torque-speed characteristic on the basis of the induction motor parameters, mathematical model or substitution schemes of the induction motor [13-17]. These methods are often used in automated electric drives, but they do not take into account the exact values of the mechanical losses and the moment of inertia. This is the reason for the additional measurement error.

One of the most labor-consuming operations that electrical machines check is the measurement of the dynamical torque-speed characteristic. The dynamical torque-speed characteristic is a very informative characteristic; it increases the probability of being able to determine certain parameters of the electrical machine, such as the starting, minimum, maximum, nominal, and critical moments. Using synchronous hollows of the dynamical torque-speed characteristic it is possible to analyze the condition of electrical machine isolation. However, due to the lack of necessary measuring devices, the dynamical torque-speed characteristic in some cases is not supervised. The main parameters of the dynamical torque-speed characteristic are the rotor inertia moment and the moment of mechanical losses. Most of the existing means for measuring the dynamical torque-speed characteristic admit, that the moment of mechanical losses is constant when actually, it is a function of the shaft angular speed. The moment of inertia is determined through different means of measurement that are all time-consuming.

Thus, there is a necessity for a more exact and automated measurement of the inertia moment and moment of mechanical losses for determining the dynamical torque-speed characteristic. This requires a computer-measuring system of the induction motor dynamical torque-speed characteristics with improved metrological parameters, which uses various modes of the induction motor operations.

The authors offer a method of measuring the dynamical torque-speed characteristic, which consists of the following.

The dynamical torque-speed characteristic is dependent on the moment on the shaft of the electrical machine $M_{d}$ at an angular speed:

$$
M_{d(\omega)}=J \cdot \frac{d \omega}{d t}+M_{0(\omega)},
$$

where $J$ - rotor inertia moment; $M_{0}$ - moment of mechanical losses; $\omega$ - angular speed of rotor; and $t$ - time. A necessary condition for its realization is the availability of the additional inertia moment $J_{m}$, executed in a kind, simple body of rotation; for example, a disk or a cylinder. The additional inertia moment size is calculated by its geometrical and weight parameters.

First, the dependence of the angular speed on time in two modes of the induction motor operation without an additional inertia moment is measured. During the time of the transient mode (after starting) the dependence of angular speed $\omega_{s}$ on time is measured, at achievement of synchronous speed the induction motor is disconnected from the power supply. Furthermore, during its self-braking mode, the dependence of angular speed $\omega_{b 1}$ on time is measured.

Third, when the induction motor has been stopped on the shaft end, the additional inertia moment $J_{m}$ is established; then, the induction motor is started. After achievement of synchronous speed the induction motor is disconnected from the power supply, and during its self-braking mode, the dependence of the angular speed $\omega_{b 2}$ on time is measured.

Accordingly, the induction motor movement equations without an additional inertia moment and with an additional inertia moment $J_{m}$ are outlined in the following equation.

$$
\left\{\begin{array}{l}
M_{e l}(\omega)=J \cdot \varepsilon_{s}(\omega)+M_{0}(\omega) \\
0=J \cdot \varepsilon_{b 1}(\omega)+M_{0(\omega)} \\
0=\left(J+J_{m}\right) \cdot \varepsilon_{b 2}(\omega)+M_{0(\omega)},
\end{array}\right.
$$

where $M_{e l}(\omega)$ - electromagnetic moment; $\varepsilon_{s}(\omega)$ - rotor angular acceleration dependence on the angular speed of the rotor throughout the transient mode (after the start); $\varepsilon_{b 1}(\omega) \overline{-}$ - rotor angular acceleration de- 
pendence on the angular speed of the rotor during its self-braking mode without the additional inertia moment; $\varepsilon_{b 2}(\omega)$ - rotor angular acceleration dependence on the angular speed of the rotor during its selfbraking mode with the additional inertia moment.

The methodical basis of an offered method is to decide on a system from three equations (2) with three unknown parameters: $M_{e l}(\omega), M_{0(\omega)}$ and $J$. After moving the unknown parameters of system (2) to the lefthand part, we obtain the following equation:

$$
\left\{\begin{array}{l}
M_{e l}(\omega)-M_{0}(\omega)-J \cdot \varepsilon_{s}(\omega)=0 \\
-M_{0(\omega)}-J \cdot \varepsilon_{b 1}(\omega)=0 \\
-M_{0(\omega)}-J \cdot \varepsilon_{b 2}(\omega)=J_{m} \cdot \varepsilon_{b 2}(\omega) .
\end{array}\right.
$$
tion:

Having decided on a common second and third equation of a system (3), we obtain the following equa-

$$
\begin{gathered}
J=J_{m} \cdot \frac{\varepsilon_{b 2}(\omega)}{\varepsilon_{b 1}(\omega)-\varepsilon_{b 2}(\omega)} ; \\
M_{0}(\omega)=J_{m} \cdot \frac{\varepsilon_{b 1}(\omega) \cdot \varepsilon_{b 2}(\omega)}{\varepsilon_{b 1}(\omega)-\varepsilon_{b 2}(\omega)} .
\end{gathered}
$$

Value of inertia moment $J$ is averaged in all ranges of the induction motor angular speed. The electromagnetic moment $M_{e l}$ is determined from the first equation of system (3)

$$
M_{e l}(\omega)=J_{m} \cdot \frac{\left(\varepsilon_{s}(\omega)-\varepsilon_{b 1}(\omega)\right) \cdot \varepsilon_{b 2}(\omega)}{\varepsilon_{b 1}(\omega)-\varepsilon_{b 2}(\omega)}
$$

$M_{e l}(\omega)$ is a dynamic electromagnetic moment without a moment of mechanical losses $M_{0}(\omega)$. The complete dynamic moment $M_{0}(\omega)$ is determined from

$$
M_{d}(\omega)=M_{e l}(\omega)+M_{0}(\omega)=J_{m} \cdot \frac{\varepsilon_{s}(\omega) \cdot \varepsilon_{b 2}(\omega)}{\varepsilon_{b 1}(\omega)-\varepsilon_{b 2}(\omega)} .
$$

The offered method can be applied to the determination of the inertia moment $J$ and moment of mechanical losses $M_{0(\omega)}$. For this purpose, it is necessary to conduct two experiences of self-braking and to determine the required parameters under the formulas (4)-(5). The offered method enables the determination of not only the dynamical torque-speed characteristic but other characteristics of the induction motor in a dynamic mode of its work [18], including:

- the electromagnetic dynamic mechanical characteristic $M_{e l}(\omega)$;

- the electromagnetic moment $M_{e l}(t)$;

- the dynamic mechanical characteristic $M_{d}(\omega)$;

- the dynamic moment $M_{d}(t)$;

- the angular speed at the induction motor's various modes $\omega=f(t)$;

- the sliding $s=f(t)$;

- the rotor inertia moment $J$; - the electromagnetic dynamic power $P_{e l}=f(t), P_{e l}=f(\omega)$ :

$$
P_{e l}=M_{e l} \cdot \omega
$$

- the mechanical dynamic power $P_{m}=f(t), P_{m}=f(\omega)$ :

$$
P_{m}=P_{e l} \cdot(1-s)
$$

- the dynamic loss in rotor winds $P_{l}=f(t), P_{l}=f(\omega)$ :

$$
P_{l}=P_{e l} \cdot s .
$$

Essentially, it enables the expansion of an area to occur using a given method.

To implement this method, an experimental computer-measuring system of the induction motor's dynamical torque-speed characteristics was developed. The appearance of the experimental setup for the computer-measuring system is shown in Figure 1, and the computer-measuring system structural scheme is shown in Figure 2. 
Induction motor's rotor (model 4A71A4CY1) with the muff is connected to an angular speed sensor (model BE-178), the output signal of which is fed to a microcontroller unit. In the experimental setup, it is possible to fix two additional flywheels on the motor shaft for implementing the proposed method of measuring the inertia moment. The electromagnetic brake, which is shown in Figure 1, is designed to study the starting characteristics of the motor and not for measuring the inertia moment.

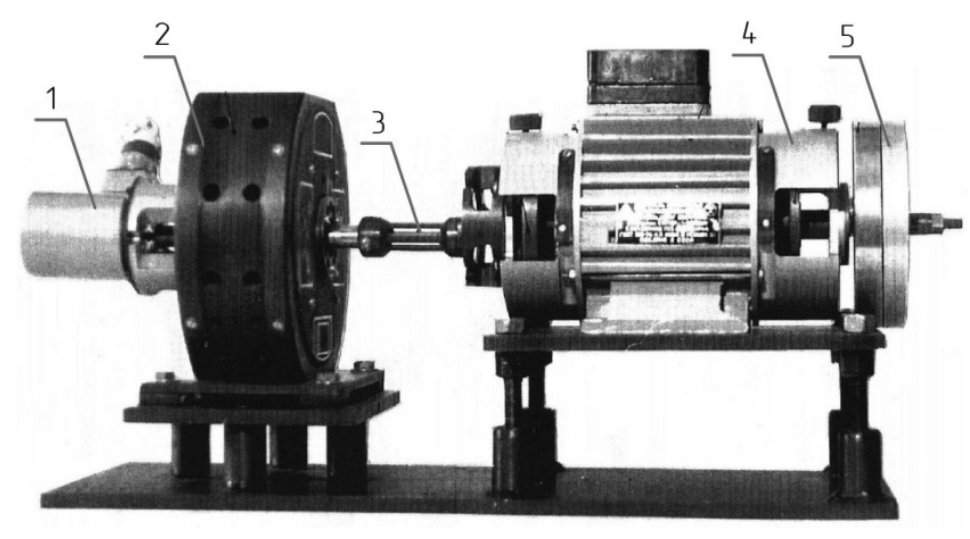

1 - angular speed sensor; 2 - electromagnetic brake; 3 - muff; 4 - investigated induction motor; 5 - additional flywheels for measurement the inertia moment

Figure 1. The appearance of the experimental setup for the computer-measuring system of the induction motor's dynamical torque-speed characteristics

The microcontroller unit uses a microcontroller manufactured by Microchip Technology Inc. and external RAM static memory chips for storing an array of measurement results. Data transfer to a personal computer (PC) is carried out through a USB interface. To convert Universal Synchronous/Asynchronous Receiver/Transmitter (USART) port signals to a USB interface, a Future Technology Devices International (FTDI) converter is used. The microcontroller provides control of the supply driver in turning the motor on and off.

In the offered computer-measuring system of the induction motor's dynamical torque-speed characteristics, the dependence of the angular speed of the motor shaft on time is measured with the aid of a digital angular sensor, which provides the formation of 1,000 pulses per revolution of the motor shaft. The time interval between the two output pulses of this sensor corresponds to the rotation of the motor shaft by $\varphi_{0}=0.36^{\circ}$. The average angular speed over a time interval between two pulses is defined as the ratio of angle $\varphi_{0}$ to this time interval.

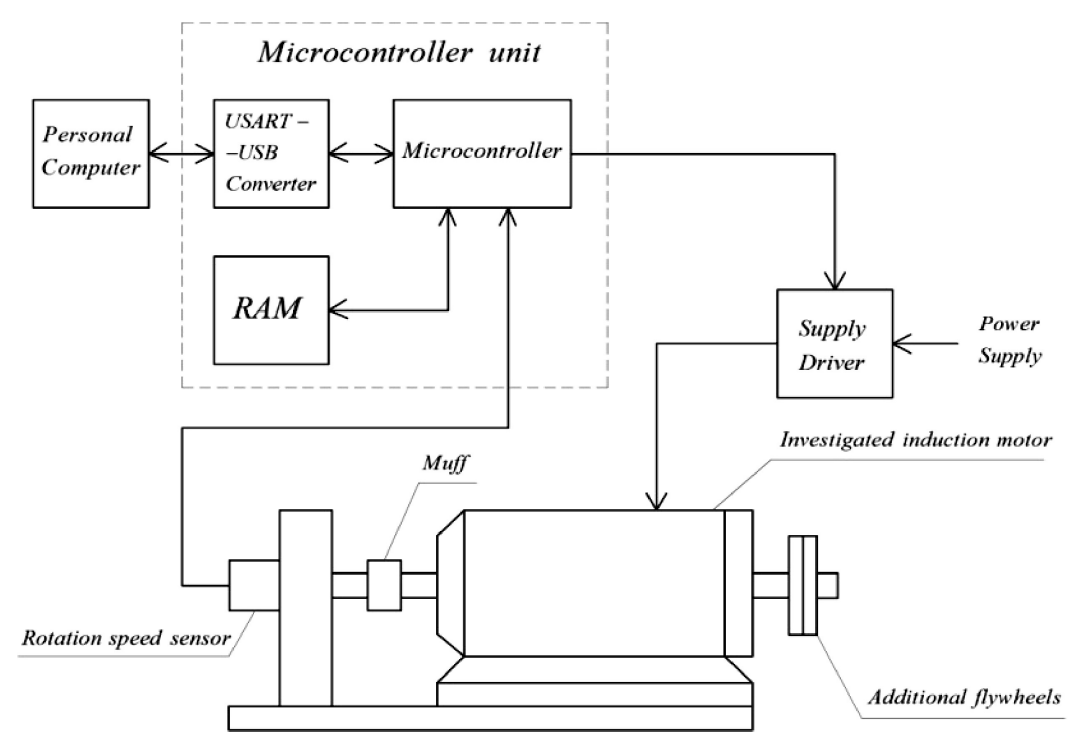

Figure 2. The structural scheme of the computer-measuring system of the induction motor's dynamical torque-speed characteristics 
In general, the algorithm of the computer-measuring system of the induction motor's dynamical torquespeed characteristics is as follows:

1. Formation of a signal to control the supply driver to turn on the motor.

2. Measuring the carrying out angular speed dependence on time during the starting of the motor.

3. Formation of a signal to control the supply driver to turn off the motor.

4. Measuring the carrying out angular speed dependence on time during the motor's self-braking mode.

5. Transfer of measurement results to a PC.

6. Attaching an additional flywheel to the motor shaft to measure the moment of inertia.

7. Repeat steps $1-5$ with the additional flywheel installed.

8. Processing of measurement information on a PC.

Figure 3 shows the experimental measurement results of the angular speed dependence on time during the starting of the motor. Figure 4 shows the experimental measurement results of the angular speed dependence on time during the motor's self-braking mode.

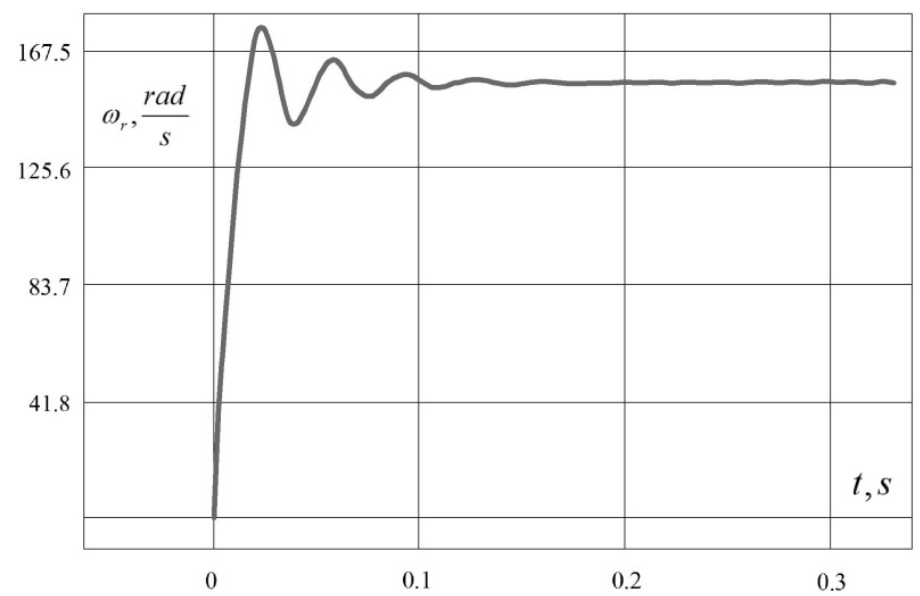

Figure 3. Experimental measurement results of the angular speed dependence on time during the starting of the motor

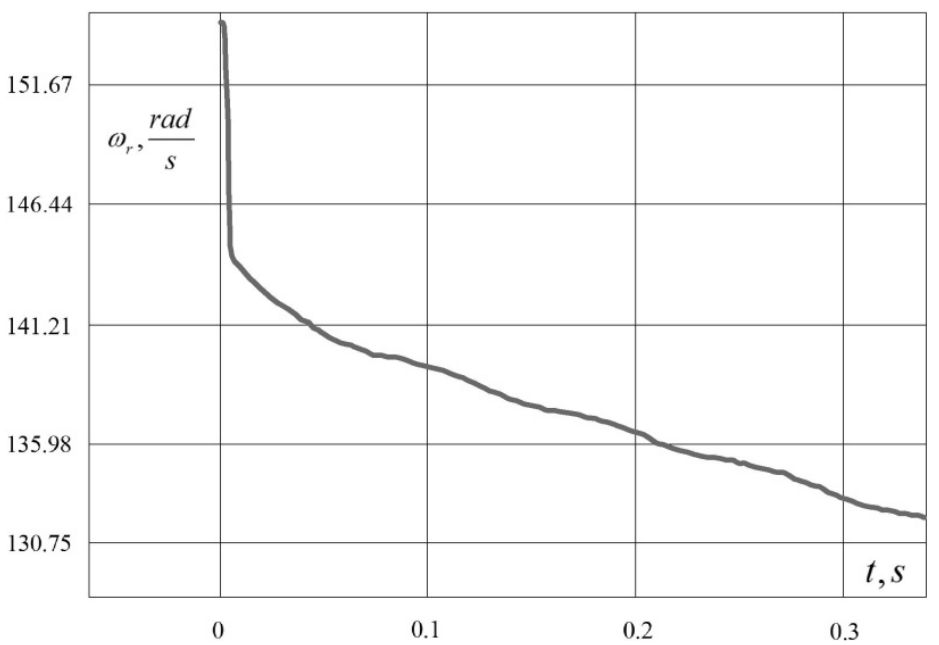

Figure 4. Experimental measurement results of the angular speed dependence on time during the starting of the motor

To determine the dependence of the angular acceleration on time for further calculation of the dynamical torque-speed characteristics, it is necessary to differentiate the dependence of the angular speed on time. Because the output signal of the sensor has a discrete character, the result of the direct differentiation of the angular speed dependence on time has a very high error. To reduce this error, it is necessary to average the results of the angular speed measurements. In our case, a moving average algorithm is used. This algorithm 
is a popular way of measuring approximate results [19]. With digital signal processing, this algorithm is very effective at suppressing parasitic high-frequency components in the measuring signal. It also does not require a large number of calculations (such as spline-approximation), which allows it to be used in real time mode. The digital processing of the angular speed measurement results is carried out as follows [19]. The additive noise $n(k)$, which has a mathematical expectation $E\{n(k)\}$, is added to the angular speed value $s$. Thus, the measurement value is described by the following expression:

$$
y(k)=s+n(k),
$$

where $k$ - the measurement number; $y$ - the measurement value of the angular speed.

To determine the assessment of the signal using the method of least squares with the loss function:

$$
V=\sum_{i=1}^{N}[y(k)-s]^{2},
$$

where $N$ - number of measurements.

From the condition $\frac{d V}{d s}=0$, we obtain the following expression for the average value of the measurement results:

$$
\hat{s} N=\frac{1}{N} \sum_{k=1}^{N} y(k),
$$

To obtain a recursive variant of the algorithm from expression (13), the previous estimate $\hat{s}(N-1)$ is subtracted, as outlined in the following equation:

$$
\hat{s}(k)=\hat{s}(k-1)+\frac{1}{k}[y(k)-\hat{s}(k-1) .
$$

With an increasing value of $k$, the influence of the individual measurement results on the $\hat{s}(k)$ decreases. If the parameter $k_{\omega}=$ const is used instead of the parameter $k$ in expression (14), the effect of all subsequent measurements will be same, and Expression (14) will take the form

$$
\hat{s}(k)=\hat{s}(k-1)+\frac{1}{k_{\omega}}[y(k)-\hat{s}(k-1)]=\frac{k_{\omega}-1}{k_{\omega}} \hat{s}(k-1)+\frac{1}{k_{\omega}} y(k)
$$

By experimentally selecting the $k_{\omega}$ parameter's value, the necessary averaging degree of the series of measurements is established.

Below are the results of the experimental measurements of the induction motor's dynamical torquespeed characteristic (Fig. 5), electromagnetic dynamic moment's dependence on time (Fig. 6), electromagnetic dynamic power's dependence on time (Fig. 7), mechanical dynamic power's dependence on time (Fig. 8), and dynamic loss in rotor wind's dependence on time (Fig. 9). The graphs show the measurement results in a thin line without using the moving average algorithm, in a thick line using the moving average algorithm.

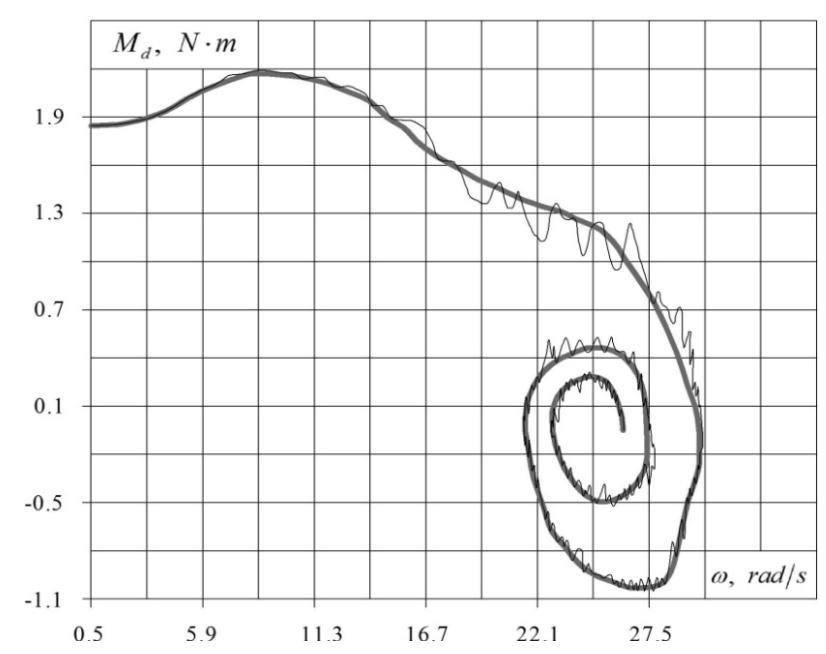

Figure 5. The induction motor's dynamical torque-speed characteristic measurement result 


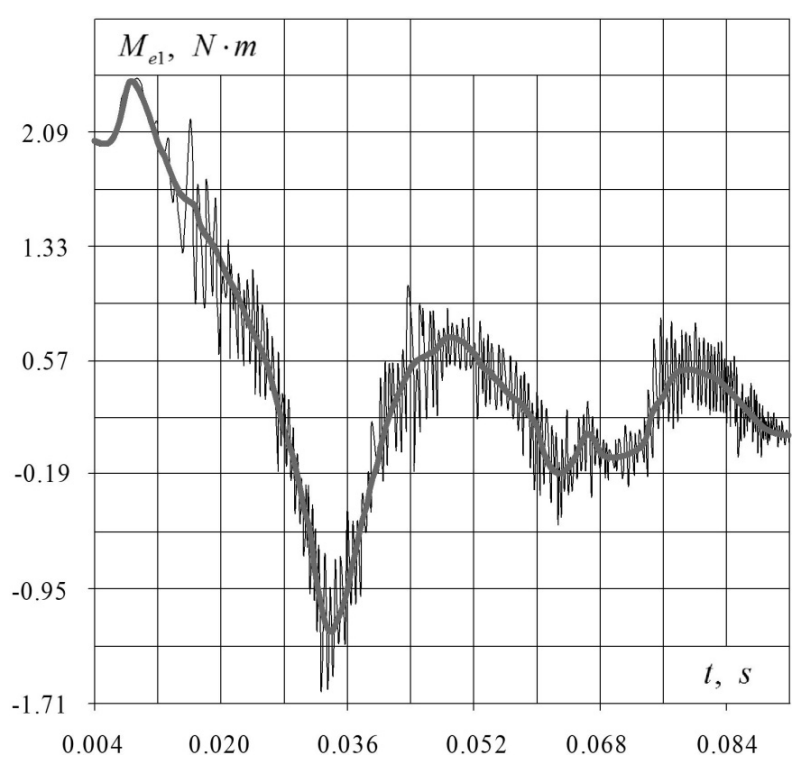

Figure 6. The electromagnetic dynamic moment's dependence on time

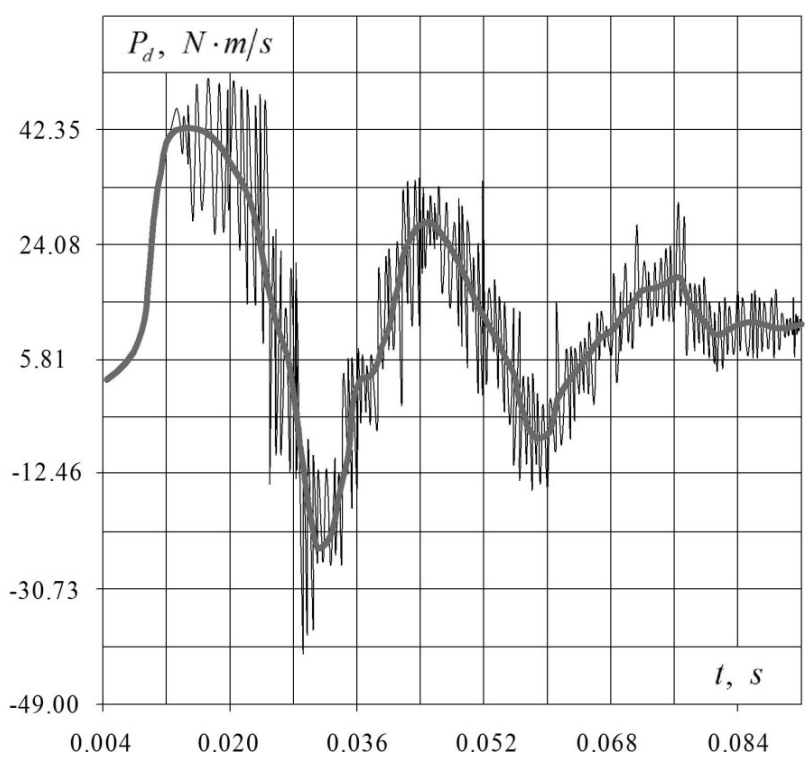

Figure 8 . The mechanical dynamic power's dependence on time

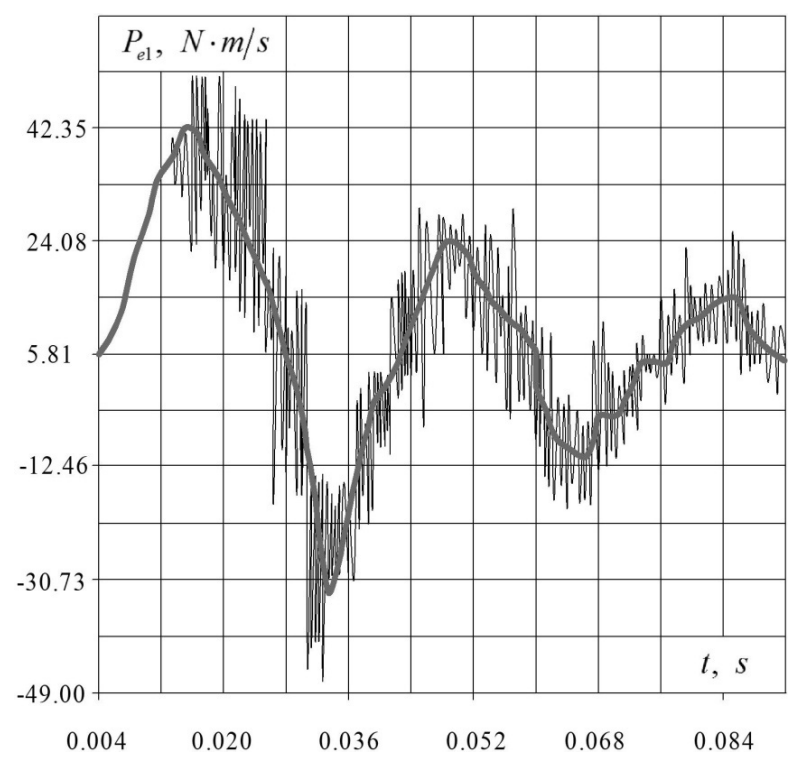

Figure 7. The electromagnetic dynamic power's dependence on time

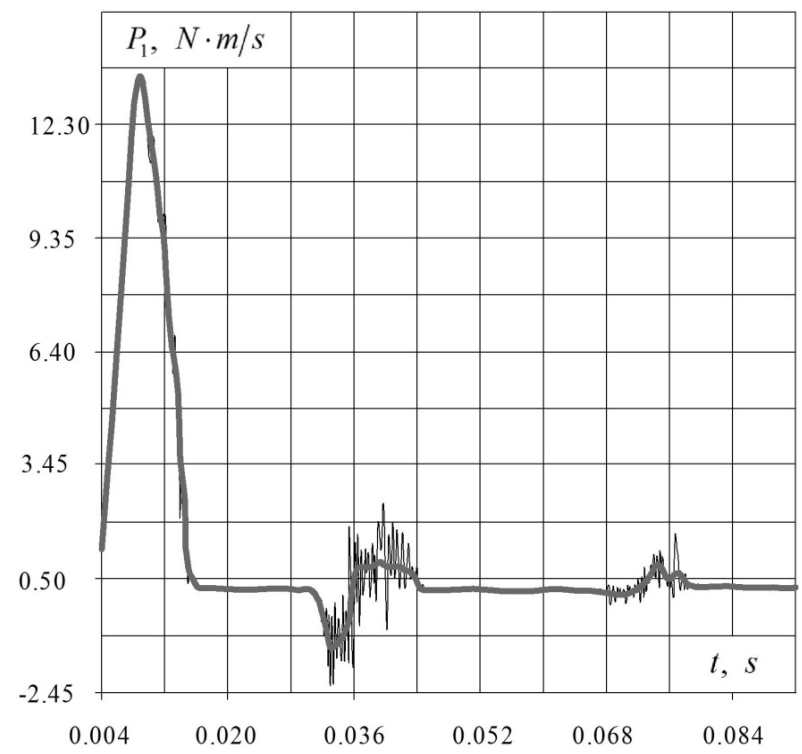

Figure 9. The dynamic loss in rotor winds' dependence on time

An experimental version of the computer-measuring system of the induction motor's dynamical torquespeed characteristics was developed. With the help of this system, the dynamical torque-speed characteristic, inertia moment, angular speed's dependence on time, electromagnetic dynamic moment's dependence on time, electromagnetic dynamic power's dependence on time, mechanical dynamic power's dependence on time, and dynamic loss in rotor winds' dependence on time were measured. The proposed system had the following basic metrological characteristics:

- Lower limit of angular speed measurement: $3 \mathrm{rad} / \mathrm{s}$;

- Upper limit of angular speed measurement: $370 \mathrm{rad} / \mathrm{s}$;

- Error of angular speed measurement $<1.5 \%$;

- Lower limit of dynamic moment: $0 \mathrm{Nm}$;

- Upper limit of dynamic moment: $30 \mathrm{Nm}$;

- Error of dynamic moment measurement $<2.5 \%$;

- Lower limit of inertia moment measurement: $0.0004 \mathrm{~kg} \cdot \mathrm{m}^{2}$; 
- Upper limit of inertia moment measurement: $0.005 \mathrm{~kg} \cdot \mathrm{m}^{2}$;

- Error of inertia moment measurement $<5 \%$.

The measuring method of the rotor moment of inertia at the use of an additional flywheel and the angular speed's dependence on time during the motor self-braking mode were proposed and implemented.

To reduce the error of direct differentiation of the angular speed's dependence on time a moving average algorithm was used. This enabled the improvement of the characteristics of the system in comparison with analogues.

\section{References}

1 IEEE Standard Test Procedure for Polyphase Induction Motors and Generators (2004). IEEE Std 112-2004 from $12^{\text {th }}$ May 2004 (Revision of IEEE Std 112-1996). New York: American National Standard Institute.

2 Anuchin, A., Shpak D., Zharkov, A., Ostrirov, V., \& Vagapov, Y. (2017). A method of determining the maximum performance torque-speed characteristic for an induction motor drive over its entire speed range. IEEE 58th International Scientific Conference on Power and Electrical Engineering of Riga Technical University (12-13 October, pp. 1-5).

3 Toman, M., Cipin, R., Mach, M., \& Vorel, P. (2017). Application of acceleration method for evaluation of induction motor torque-speed characteristics. IEEE International Conference on Environment and Electrical Engineering and IEEE Industrial and Commercial Power Systems Europe (6-9 June, pp. 1-4).

4 Bodolai, T. (2010). Computer-aided Measurement Method for Determination of Torque-Speed Characteristics of Electrical Motors Used in Practical Education. Journal of Physics, 1, 1-7.

5 Natrasevschi, A. (1971). Installation and Method of Recording Electric Motor's Torque-Speed Curve Under Steady-State and Dynamic Regimes. IEEE Transactions on Industry and General Applications, 7, 500-503.

6 Selim H., \& Girgis, G.A. (1986). Microprocessor-Based Digital Accelerometer and its Application in an Instrument for Motor Torque-Speed Characteristic Display During the Transient Interval. IEEE Transactions on industrial electronics, 44-48.

7 Buinac, R., \& Tomljenovic, V. (2013). Determination of the torque-speed characteristic of induction motor in electric machinery education. 36th International Convention on Information and Communication Technology, Electronics and Microelectronics (20-24 May, pp. 765-769).

8 Szabados, B., Dableh, J.H., Findlay, R.D., \& Stafford, D. (1989). A new approach for measurement of the torque-speed characteristics of induction motors. Fourth International Conference on Electrical Machines and Drives (13-15 September, pp 246-350).

9 Szabados, B., Dableh, J.H., Findlay, R.D., Obermeyer, G.M., \& Draper, R.E. (1990). Measurement of the torque-speed characteristics of induction motors using an improved new digital approach. EEE Transactions on Energy Conversion, 5, 565-571.

10 Chan, T.F. (1993). Determination of the Torque-Speed Characteristic of an Induction Motor Using a Curve-Fitting Technique. International Journal of Electrical Engineering Education, 366-373.

11 Bellini, A., Figalli, G., \& Ulivi, G. (1986). A Microcomputer-Based Optimal Control System to Reduce the Effects of the Parametric Variations and Speed Measurement Errors in Induction Motor Drives. IEEE Transactions on Industry Applications, 22, 42-50.

12 Cipin, R., Patocka, M., \& Vondrus, J. (2011). Acceleration method of the IM torque-speed characteristics measurement. International Conference on Power Engineering, Energy and Electrical Drives (11-13 May, pp. 1-5).

13 Aree, P. (2016). Analytical approach to determine speed-torque curve of induction motor from manufacturer data. Procedia Computer Science, 293-296.

14 Niu, S., Ho, S.L., \& Fu, W. (2015). Fast Computation of Torque-Speed Characteristics of Induction Machines. IEEE International Magnetics Conference (11-15 May, p. 1).

15 Emmrich, K., Brune, A., \& Ponick, B. (2014). Evaluation of an Analytical, Efficiency-Optimized Torque-Speed Characteristic of Induction Machines Coupled with a Thermal-Electromagnetic Energy Consumption Calculation. International Conference on Electrical Machines (2-5 September, pp. 762-767.).

16 Pfingsten, G., \& Hameyer, K. (2017). Highly efficient approach to the simulation of variable-speed induction motor drives. Science Measurement \& Technology IET, 11, 793-801.

17 Kojooyan-Jafari, H., Monjo, L., Corcoles, F., \& Pedra, J. (2014). Parameter Estimation of Wound-Rotor Induction Motors From Transient Measurements. IEEE Transactions on Energy Conversion, 29, 300-308.

18 Podzharenko, V.O., \& Kucheruk, V.Y. (1996). Computer-Measuring System of the Mechanical Characteristics of Electrical Drives. Conference of Electrical Drives and Power Electronics (1-3 October 1996, pp. 633-637).

19 Iserman, R. (1981). Digital Control Systems. Berlin: Springer-Verlag. 
В.Ю. Кучерук, И.П. Курытник, Е.З. Ошанов, П.И. Кулаков, А.А. Семенов, Д.Ж. Карабекова, А.К. Хасенов

\title{
Асинхронды қозғалтқыштың айналмалы моментінің динамикалык сипаттамаларын компьютерлік-өлшеу жүйесі
}

\begin{abstract}
Мақалада асинхронды қозғалтқыштардың және оны іске асыру үшін компьютерлік-өлшеу жүйесінің айналмалы моментінің динамикалық сипаттамасын анықтаудың тиімді әдісі қарастырылды. Бұл әдіс қосымша маховикті қолданып және бұрыштық жылдамдықты динамикалық өлшеу, бастапқы, өтпелі процесс аяқталғаннан кейін және асинхронды қозғалтқыштың өзін-өзі тежеу режимінде орындалатын уақыт функциясы ретінде қолданылды. Өлшеу нәтижесінде алынған деректерді аппроксимациялау үшін жылжымалы орта алгоритмі пайдалынды. Сонымен қатар бұл жүйенің көмегімен инерция моменті, бұрыштық жылдамдықтың уақытқа тәуелділігі, электрмагниттік динамикалық моменттің, электрмагниттік динамикалық қуаттың, механикалық динамикалық қуаттың, және ротор желдеріндегі динамикалық шығындардың уақытқа тәуелділіктері өлшенеді. Мақалада ұсынылған компьютерлікөлшеу жүйесін пайдалана отырып, асинхронды қозғалтқыштың сипаттамаларын эксперименттік өлшеу нәтижелері келтірілген. Ұсынылған жүйе эксперименттік болып табылады және одан әрі оларды өндіру процесінде асинхронды қозғалтқыштарды сынау үшін пайдаланылуы мүмкін.
\end{abstract}

Кілт сөздер: компьютерлік-өлшеу жүйесі, динамикалық жылдам-жылдамдық сипаттамасы, асинхронды қозғалтқыш, жылжымалы орта алгоритмі.

\section{В.Ю. Кучерук, И.П. Курытник, Е.З. Ошанов, П.И. Кулаков, А.А. Семенов, Д.Ж. Карабекова, А.К. Хасенов \\ Компьютерно-измерительная система динамических характеристик крутящего момента асинхронного двигателя}

В статье рассмотрен эффективный метод определения динамической характеристики вращательного момента асинхронных двигателей и компьютерно-измерительной системы для его реализации. В этом методе использованы дополнительный маховик, динамические измерения угловой скорости, как функции времени, выполняющегося в начале, также после окончания переходного процесса и в режиме самоторможения асинхронного двигателя. Для аппроксимации данных, полученных в результате измерений, применен алгоритм скользящего среднего. Кроме того, с помощью этой системы измеряются момент инерции, а также зависимости (от времени) угловой скорости, электромагнитного динамического момента, электромагнитной динамической мощности, механической динамической мощности и динамических потерь в ветрах ротора. В статье приведены результаты экспериментальных измерений характеристик асинхронного двигателя с использованием предложенной компьютерноизмерительной системы. Предложенная система является экспериментальной и в дальнейшем может быть использована для испытаний асинхронных двигателей в процессе их производства.

Ключевые слова: компьютерно-измерительная система, динамическая моментно-скоростная характеристика, асинхронный двигатель, алгоритм скользящего. 